\title{
Two enteric coated microspheres in cystic fibrosis
}

\author{
J Williams, A MacDonald, P H Weller, J Fields, H Pandov
}

\begin{abstract}
In a randomised single blind crossover study in children with cystic fibrosis and pancreatic insufficiency, two enteric coated microsphere preparations of pancreatin were compared on a capsule for capsule basis, by measuring the coefficient of fat absorption, nitrogen excretion, weight change, and symptom scores after four weeks' treatment with each preparation. Thirty nine subjects were randomly allocated to receive Pancrease followed by Creon or vice versa. Each individual subject received the same number of capsules per day in each study period. Data from 27 children (Pancrease/Creon, $n=13$ and Creon/Pancrease, $n=14$ ) were suitable for analysis. Results showed no significant differences between the two preparations in any variable studied. We conclude that there is no significant difference between Pancrease and Creon when compared on a capsule for capsule basis.
\end{abstract}

Pancreatic insufficiency occurs in most patients with cystic fibrosis. ${ }^{1}$ Although standard pancreatic enzyme preparations produce some improvement in fat absorption, ${ }^{2}$ the majority of lipase administered in this form is inactivated in the acid environment of the stomach. In adults with chronic pancreatic insufficiency it has been shown that less than $8 \%$ reaches the duodenum ${ }^{3}$ with the result that symptoms of malabsorption may persist which, in children, would lead to continuing poor growth.

With the introduction of enteric coated microspheres fat absorption can be improved significantly. ${ }^{4-7}$ Enzymes are better protected during gastric transit by an acid resistant coating, delaying release of enzyme until the $\mathrm{pH}$ has risen to at least $5 \cdot 5$. In addition, a proportion of microspheres are sufficiently small to avoid gastric retention. The net result is that a larger percentage of active enzyme may be available in the duodenum and a normal fat diet is therefore likely to be better tolerated.

Another advantage of these new preparations is that, as a result of increased efficiency, fewer capsules are needed to achieve near normal fat absorption, a factor likely to encourage compliance in a group of patients already subjected to a demanding treatment schedule.

Pancrease (Cilag) and Creon (Duphar) are two enteric coated preparations commonly available in the United Kingdom. Both preparations are presented as microspheres within a hard gelatin capsule, but their manufacture and enzyme content are appreciably different.
Pancrease microspheres are produced by evenly spraying pancrealipase of small particle size around small nonpareil seeds that are then enteric coated (data on file, McNeil Pharmaceutical, Spring House, PA 19477, USA). The production of Creon microspheres involves pelletising, spheronising, and enteric coating pancreatin in a fluid bed system (Creon Training Manual: KaliChemie AG, Pharmaceutical Division, Hannover 1984).

The stated enzyme content for the two preparations differs considerably (table 1). By comparison with Pancrease, Creon contains about $60 \%$ more lipase and $210 \%$ more amylase per capsule. The protease content is $63 \%$ of that in Pancrease. In vitro studies have shown that enzyme release may occur at a lower $\mathrm{pH}$ for Pancrease than for Creon and that the presence of bile salts may also influence lipase release, accelerating release from Creon at $\mathrm{pH}$ values less than $6 \cdot 0 .{ }^{8}$ Studies have also shown, however, that the dissolution of microsphere enteric coating can occur throughout a wide range of $\mathrm{pH}$ values and at a high $\mathrm{pH}$ may take as long as 18 minutes. ${ }^{9}$ In addition, the proportion of 'optimum' sized microspheres varies considerably between the preparations currently available, although more than $90 \%$ of them are less than $2 \mathrm{~mm}$ in diameter and none are larger than $3 \mathrm{~mm} .{ }^{10}$ Lastly, the same study has demonstrated in vivo that there is interindividual variation in the rate of gastric emptying of varying sizes of spheres.

All these variables may affect the actual quantity of enzyme available for digestion in individual patients and might suggest that the lipase content estimated to be contained in each preparation is not the only consideration to be taken into account when estimating enzyme dosage. This study was therefore designed to compare the in vivo efficacy of two enteric coated microspheres on a capsule for capsule basis.

\section{Patients and methods}

Thirty nine children with a median age of $9 \cdot 7$ (range 5-17) years were entered into the study. All had symptoms of cystic fibrosis, at least two abnormal sweat test results, and proved pan-

Table 1 Comparative enzyme content of supplements in units $(B P)$ per capsule

\begin{tabular}{lcc}
\hline & Pancrease & Creon \\
\hline Lipase & 5000 & 8000 \\
Amylase & 2900 & 9000 \\
Protease & 330 & 210 \\
\hline
\end{tabular}




\begin{tabular}{|c|c||c|c|c|c||c|c|c|c|}
\hline \multicolumn{1}{|l||}{ Run in period } & \multicolumn{3}{c||}{ Preparation A } & \multicolumn{4}{c|}{ Preparation B } \\
\hline 1 & 2 & 3 & 4 & 5 & 6 & 7 & 8 & 9 & 10 \\
\hline & & & & & & & & & \\
\hline
\end{tabular}

Standard menu and symptom diary card

Figure I Study design comparing two pancreatic enzyme preparations in children with cystic fibrosis. consistent results with a variance of only $2 \cdot 6 \%$. The coefficient of fat absorption was calculated using the formula:

$$
\frac{\text { Fat intake }(\mathrm{g})-\text { fat excretion }(\mathrm{g})}{\text { Fat intake }(\mathrm{g})} \times 100 \%
$$

After recruitment all patients were seen at the end of weeks 2, 6, and 10. At each visit an assessment of general condition was made by both doctor and patient using a visual analogue score (maximum score 200). Patients' weights were recorded and converted to percent weight for age $^{16}$ to allow direct comparison of all patients.

During weeks 2, 6, and 10 the children, assisted by parents where necessary, kept a symptom diary recording appetite, number, colour, and consistency of stools, incidence of abdominal pain, and general condition. Children were asked to give a score out of 10 , based on a linear analogue score, for each symptom on each day of the study week. The number of capsules consumed daily was also recorded. Unused capsules were returned for counting at the end of each study period. At the end of the study, children were asked to state their own preference of pancreatic enzyme supplement.

Statistical analysis was carried out using the multivariate method of Lehmacher. ${ }^{17} \mathrm{Calcu}$ lation of a sample size of 30 was made using standard deviations from an unpublished similar study (Harms, Bertele. Cilag AG, report PAN 01175, Acc No 41671; Munich: 1982) to detect a $10 \%$ difference in fat absorption with a power of $80 \%$ to achieve significance at the $5 \%$ level.

Informed consent was obtained from all parents. The study was approved by the Central Birmingham Health Authority ethical committee. fat intake was analysed using standard food tables, ${ }^{13}$ immigration food tables, ${ }^{14}$ and food composition data from many food manufacturers.

All patients were taking either Pancrease or Creon on entry to the study. During the run in period the dose for each individual was reevaluated and adjusted to minimise symptoms and signs of malabsorption. At the end of this period, patients were randomly assigned to receive Pancrease followed by Creon or vice versa, each for four weeks. Each individual subject was then instructed to take the same total daily number of capsules, whether Pancrease or Creon, for the duration of the study. Trial medication was issued by the hospital pharmacist and the order of treatments was blinded to the doctor but not to the patients, as they were taking standard commercial preparations of the enzymes.

Three day stool collections were performed at home at the end of weeks 6 and 10, starting on the fourth day of the standardised menu. Timing was chosen to minimise disturbance to schooling. Faecal fat was measured using the method of Van der Kamer $e t a l^{15}$ and faecal nitrogen using a Tecator Kjeltec Automodel 1030 nitrogen analyser. Faecal fat analysis performed using this method produced very

\section{Results}

Twelve patients were unsuitable for analysis. Of these seven withdrew because of respiratory exacerbations or infective illnesses that interfered with dietary intake such that their standard individualised menu could not be followed. One failed to attend for follow up and one withdrew because of intolerable symptoms of steatorrhoea on Pancrease. Further assessment on Creon (her usual treatment) showed poor control of fat malabsorption with a coefficient of fat absorption of $77 \%$. Three patients inadvertently took unequal numbers of capsules during the two study periods and were therefore excluded from the analysis.

The remaining 27 children ( 15 boys and 12 girls) completed the study. Daily pancreatic enzyme dosage ranged from five to 37 capsules (median 20). All patients took an unrestricted diet with a median (range) fat intake of 2.64 $(0 \cdot 92-4 \cdot 12) \mathrm{g} / \mathrm{kg} /$ day. Dietary management was excellent and dietary fat intake varied very little between the two study periods (table 2$)(p=0 \cdot 19)$.

FAT ABSORPTION (TABLE 3)

There was no significant difference in the 
Table 2 Dietary fat intake (g/day) during each treatment period. Results are median (range)

\begin{tabular}{|c|c|c|}
\hline $\begin{array}{l}\text { Treatment } \\
\text { order }\end{array}$ & Pancrease & Creon \\
\hline $\begin{array}{l}\text { Pancrease/Creon } \\
\text { Creon/Pancrease }\end{array}$ & $\begin{array}{l}67 \cdot 7(48 \cdot 0-128 \cdot 3) \\
78 \cdot 9(30 \cdot 5-127 \cdot 30)\end{array}$ & $\begin{array}{l}66 \cdot 2(48 \cdot 0-128 \cdot 3) \\
78 \cdot 1(30 \cdot 5-125 \cdot 5)\end{array}$ \\
\hline
\end{tabular}

Table 3 Coefficient of fat absorption for individual subjects (and median) during each treatment period

\begin{tabular}{|c|c|c|}
\hline Patient No & Pancrease & Creon \\
\hline $\begin{array}{r}2 \\
5 \\
7 \\
11 \\
12 \\
17 \\
23 \\
24 \\
30 \\
32 \\
33 \\
37 \\
39\end{array}$ & $\begin{array}{l}\text { Pancrease/Creon } \\
89 \cdot 07 \\
95 \cdot 43 \\
91 \cdot 32 \\
93.64 \\
91 \cdot 54 \\
82 \cdot 17 \\
93 \cdot 32 \\
55 \cdot 11 \\
93 \cdot 89 \\
92 \cdot 15 \\
81 \cdot 06 \\
80 \cdot 63 \\
87 \cdot 29\end{array}$ & $\begin{array}{l}90 \cdot 48 \\
92 \cdot 82 \\
92 \cdot 36 \\
92 \cdot 91 \\
93.05 \\
92 \cdot 21 \\
94 \cdot 86 \\
94.93 \\
86.98 \\
83.01 \\
74 \cdot 17 \\
98 \cdot 79 \\
70 \cdot 42\end{array}$ \\
\hline Median & $91 \cdot 32$ & $92 \cdot 36$ \\
\hline $\begin{array}{r}1 \\
3 \\
9 \\
10 \\
15 \\
16 \\
18 \\
19 \\
20 \\
22 \\
26 \\
29 \\
35 \\
36\end{array}$ & $\begin{array}{l}\text { Creon/Pancrease } \\
94 \cdot 30 \\
87 \cdot 93 \\
83 \cdot 68 \\
62 \cdot 41 \\
92 \cdot 31 \\
72 \cdot 11 \\
95 \cdot 50 \\
84 \cdot 93 \\
87 \cdot 83 \\
90 \cdot 02 \\
95 \cdot 52 \\
76 \cdot 84 \\
94 \cdot 02 \\
23 \cdot 28\end{array}$ & $\begin{array}{l}91 \cdot 25 \\
82 \cdot 00 \\
84 \cdot 72 \\
88 \cdot 19 \\
85 \cdot 49 \\
85 \cdot 42 \\
92 \cdot 25 \\
65 \cdot 58 \\
83 \cdot 96 \\
82 \cdot 20 \\
86 \cdot 55 \\
66 \cdot 86 \\
92 \cdot 90 \\
79 \cdot 67\end{array}$ \\
\hline Median & $87 \cdot 88$ & $85 \cdot 07$ \\
\hline
\end{tabular}

coefficient of fat absorption between Pancrease and Creon, regardless of the order of treatments $(\mathrm{p}=0 \cdot 36)$.

\section{NITROGEN EXCRETION}

Nitrogen excretion (g/day) showed no significant difference between the two treatments (Pancrease: mean (SD) $1.23(1.0)$ and Creon: $1 \cdot 40(1 \cdot 1) ; \mathrm{p}=0 \cdot 28)$.

\section{WEIGHT CHANGE (FIG 2)}

There were no significant differences in weight gain between the treatment periods on Pancrease or Creon $(p=0.98)$. Not surprisingly, when weight was considered as a percent of weight for age there was still no difference $(\mathrm{p}=0 \cdot 46)$.

\section{SYMPTOM SCORES}

There were no significant differences in scores in either treatment period for any symptom (Pancrease: mean (SD) $5.9(1.24)$ and Creon: $5.9(1 \cdot 12) ; p=0.77$ for all symptoms). Assessment of general condition at clinic visits by both patient and doctor did not show any differences (patient: $\mathrm{p}=0 \cdot 8$; doctor: $\mathrm{p}=0 \cdot 15$ ).

Analysis using $\chi^{2}$ showed no significant difference in preference for one or other product $(p=0 \cdot 24)$, being roughly equally divided between Pancrease $(n=11)$ and Creon

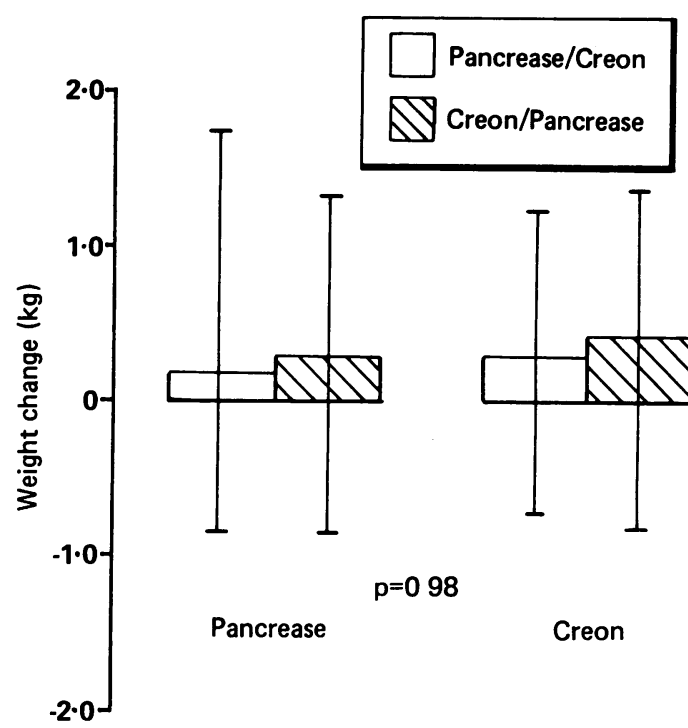

Figure 2 Change in weight (median and range) during each treatment period.

$(n=9)$; seven patients showed no preference. Of those who showed a preference, nine patients chose the preparation that had previously been taken and 11 chose the opposite. Preference for the preparation that gave a better coefficient of fat absorption was expressed by $10 / 20$ patients. Of those children who expressed no preference, only two had a difference in fat absorption greater than $5 \%$.

\section{Discussion}

Our results show that Pancrease and Creon are equally efficient, on a capsule for capsule basis, at improving fat absorption to normal or near normal levels, although the doses required to achieve this are frequently higher than those recommended by the manufacturers.

In $19(70 \%)$ of our children dietary fat absorption was above $80 \%$ and in eight $(30 \%)$ it was greater than $90 \%$ on both treatments. Indeed, all patients were able to achieve a coefficient of fat absorption of greater than $80 \%$ on one or other preparation. Dosage was determined during the run in period based entirely on abdominal symptoms and signs and this dose was confirmed by faecal fat estimation to be adequate, in most cases, to achieve good fat absorption.

That the two preparations were equally efficient, despite their different stated lipase contents, suggests that other variables have a significant effect on the efficiency of fat absorption. Other studies, comparing the same enteric coated enzyme preparations in vivo, also showed no significant differences, although the preparations were compared in these studies on the basis of measured lipase content. ${ }^{6}{ }^{18}$ Both these studies, however, were unblinded and one was unrandomised. Despite these failings the similar findings could be argued to be supporting evidence that actual dosage of lipase prescribed is not so important as other factors, which include gastric acid secretion, endogenous pancreatic enzyme and bicarbonate secretion, bile salt concentration in the duo- 
denum, ${ }^{8}$ and the in vitro variation in availability of enzymes from different microsphere preparations. These factors may also help to explain why there are a few patients in whom one preparation is significantly superior to the other.

In addition, compliance must be considered in a study where children are already established on one of the test preparations. It was necessary to exclude three patients because of poor compliance with enzyme dosage (greater than $20 \%$ difference between treatment periods), identified by capsule counts at the end of the study and by discrepant capsule counts recorded on their diary cards; however, there is no objective evidence to suggest that compliance was a problem in any other subjects. In a few cases there were remarkable differences in fat absorption that remain unexplained, and for which poor compliance may be partially responsible. There was no significant difference in preference for one or other of the enzyme preparations at the end of the study, however, or for the 'familiar' or the 'new' preparation.

There were no significant differences between the two preparations in any variable examined in this study, providing good evidence that the two preparations are equally efficient in vivo when used in equal numbers of capsules. This might suggest that Pancrease is a slightly more efficient preparation, perhaps because of the lower $\mathrm{pH}$ at which enzyme appears to be released. The effect of the presence of bile salts on enzyme release from both preparations is hypothetical and requires further study. ${ }^{9}$ The smaller percentage of microspheres of 'optimum' size ${ }^{10}$ in Pancrease would seem to contradict this superiority but in vivo does not appear to be important. Similarly, partial dissolution of enteric coating at low pH values with some loss of enzyme activity would seem to be disadvantageous but in fact may confer some benefit by improving the timing of enzyme release in the duodenum. ${ }^{9}$

It remains to be seen whether the introduction of these more efficient enzyme preparations will have an important effect on prognosis. Their many advantages for the patient include the ability to tolerate a normal fat diet, the lower number of capsules required because of their increased efficiency, and the relative lack of taste. These features make an appreciable contribution to a better quality of life.
We conclude that, despite the smaller quantity of measured lipase contained in Pancrease, there was no significant difference between the two pancreatic enzyme preparations when used on a capsule to capsule basis. This suggests that lipase content alone is not a total predictor of the comparative clinical performance of enzyme products and that other factors such as the release profile of the microspheres and individual variability in gastrointestinal dysfunction may be important.

We thank the patients and parents for their cooperation in this study. We also thank Dr I W Booth for his invaluable comments on the manuscript and Cilag Limited for supplies of microspheres.

JW was supported financially by Cilag Limited.

1 di Sant-Agnese PA. Recent observations on pathogenesis of cystic fibrosis of the pancreas. Pediatrics 1959;24:313-20.

2 Lapey A, Kattwinkel J, di Sant-Agnese PA, Laster L. Steatorrhoea and azotorrhoea and their relation to growth and nutrition in adolescents and young adults with cystic fibrosis. I Pediatr 1974;84:328-34.

3 DiMagno EP, Malagelada JR, Go VL, Moertel CG. Fate of orally ingested enzymes in pancreatic insufficiency. Comparison of two dosage schedules. $N$ Engl $\mathcal{f} M e d$ 1974;296:1318-22.

4 Graham DY. An enteric-coated pancreatic enzyme preparation that works. Dig Dis Sci 1979;24:906-9.

5 Mischler EH, Parrell S, Farrell PM, Odell GB. Comparison of effectiveness of pancreatic enzyme preparations in cystic fibrosis. Am $\mathcal{Y}$ Dis Child 1982;136:1060-3.

6 Beverley DW, Kelleher J, MacDonald A, Littlewood JM, Robinson T, Walters MP. Comparison of four pancreatic extracts in cystic fibrosis. Arch Dis Child 1987;62:564-8.

7 Stead RJ, Skypala I, Hodson ME, Batten JC. Enteric-coated microspheres of pancreatin in the treatment of cystic fibrosis: comparison with a standard enteric-coated preparation. Thorax 1987;42:533-7.

8 Littlewood JM, Kelleher J, Walters MP. In vivo and in vitro studies of microspheres pancreatic supplements. $\mathcal{F}$ Pediatr Gastroenterol Nutr 1988;7(suppl 1):522-9.

9 Sackman JW, Smith KE, Graham DY. Does mixing pancreatic enzyme microspheres (Pancrease) with food damage the enteric-coating? $\mathcal{f}$ Pediatr Gastroenterol Nutr 1982;1: 333-5.

10 Meyer JH, Elashoff J, Porter-Fink V, Dressman J, Amidon L. Human postprandial gastric emptying of 1-3-millimeter spheres. Gastroenterology 1988;94:1315-25.

11 Brown GA, Sule D, Williams J, Puntis JWL, Booth IW, McNeish AS. Faecal chymotrypsin: a reliable index of exocrine pancreatic function. Arch Dis Child 1988;63: 785-9.

12 Puntis JWL, Berg JD, Buckley BM, Booth IW, McNeish AS. Simplified oral pancreatic function test. Arch Dis Child 1988;63:780-4.

13 Paul AA, Southgate DAT. McCance and Widdowson. The composition of foods. 4th Ed. London: HMSO, 1978.

14 Ian SP, Wenloch RW, Buss DH. Immigrant foods. McCance and Widdowson. The composition of foods. Second supplement. London: HMSO, 1985.

15 Van de Kamer JH, ten Bokkel Huinink H, Weyers HA. Rapid method for the determination of fat in faeces. $\mathcal{F}$ Bio Chem 1949;177:347-55.

16 Cole TJ, Donnet ML, Stanfield JP. Weight for height indices to assess nutritional status-a new index on a slide rule. $A m$ $\mathcal{f}$ Clin Nutr 1981;34:1935-43.

17 Lehmacher $W$. Verlaufskurven und Crossover. In: Verbala $\mathrm{K}$, Relichertz PL, Victor N, eds. Medizinische Informatik und Statistik. Berlin: Springer-Verlag, 1987:77-150.

18 George DE, et al. Comparative effectiveness of two pancreatic supplements in patients with cystic fibrosis. Pediatr Pulmonol 1987:suppl 1:139. 